\title{
Care for Unaccompanied Children in Croatia: The Roles and Experiences of Special Guardians
}

\author{
Drago ŽUPARIĆ-ILJIĆ \\ Department of Sociology, Faculty of Humanities and Social Sciences, \\ University of Zagreb, Croatia \\ dzuparic@ffzg.hr \\ Dubravka MLINARIĆ \\ Institute for Migration and Ethnic Studies, Zagreb, Croatia \\ dubravka.mlinaric@imin.hr
}

\begin{abstract}
In the period from 2011 to 2017, there was a fluctuating yet notable increase of unaccompanied minors transiting through Croatia. The 2015 and 2016 events involving the Balkan corridor included a significant number of unaccompanied and separated children, who count as vulnerable groups of refugees and migrants. State policies and measures aimed at providing care and protection to these groups include mechanisms of appointing special guardians, who are tasked with safeguarding their rights and providing general assistance within the system of care during their stay and/or during the status recognition procedure. Using a desk study of relevant accessible documents together with a thematic content analysis of 26 expert interviews that were conducted in three cycles; in 2014, 2016, and 2018 with relevant stakeholders and care providers, the authors discussed the experiences of practitioners in the field and some of the most important challenges they are facing within the special guardianship system. The general role of caregivers in the reception, integration and possible family reunification of unaccompanied children was also examined. The results suggested that due to short period of their stay in Croatia, and due to systemic insufficiencies within the system of care, the state is facing inconsistencies in the implementation of existing European Union standards and of national measures. The special guardianship care system for unaccompanied and separated children, which is moderately influenced by the 2015 and 2016 Balkan corridor experience, has been limited by lack of professional and financial resources, lack of stronger institutional support and somewhat overlapping competences of different parties in the system of care.
\end{abstract}

Key words: unaccompanied children, special guardianship, family reunification, asylum in Croatia, Balkan corridor 


\section{Introduction}

The displacement of unaccompanied and separated children is a particularly diverse, complex and multifaceted phenomenon because children flee from war and conflict zones, and from deprived environments where their lives, freedom or means of livelihood are being threatened. The United Nations Children's Fund estimated that in 2016, 28 million children were being uprooted by violent conflicts (UNICEF, 2016: 1), meaning that nearly half of the displaced population in the world that year were children. The arrival of 1.3 million of refugees and forced migrants to Europe during 2015 and 2016 actualised the problem of the personal safety of the displaced children and members of their families. In 2015, around 389,000 children applied for protection in 32 European countries (UNICEF, 2016: 92). The UNHCR report (2015) warned that the number of "unaccompanied and separated children" has increased, especially of those who are nationals of Syria, Iraq, Afghanistan and Eritrea. The absence of accurate statistics on the exact number of unaccompanied and separated children in the recent movements is a major methodological problem, although the UNICEF (2017: 12) estimated that "[i]n 2015 and 2016, among nearly 800,000 children who had applied for asylum in Europe, 170,000 were considered unaccompanied". According to the Croatian Ministry of the Interior, 169 unaccompanied children were registered as asylum seekers in Croatia in those years. ${ }^{1}$

From the spring of 2015 until the spring of 2016, a humanitarian crisis was witnessed relating to the increased arrival and transit of refugees through the Eastern Mediterranean and Balkan corridors, heading to Western Europe, mostly to Germany. Even though forced migration is oftentimes a prerequisite for bare survival, hazardous journeys across the Mediterranean pose significant risks for children, their families and relatives. ${ }^{2}$ Even prior to the full European Union (EU) membership, Croatia had been an important transit territory on the (Western) Balkan migration route owing to its specific geographic position which links southeast Europe with its central and western parts. Its territory serves as one of

\footnotetext{
${ }^{1}$ The Ministry of the Interior's official reply on "Statistika o maloljetnicima bez pratnje u RH na dan 31.12.2015. [Statistics on unaccompanied minors in the Republic of Croatia on 31 December 2015]", private e-mail correspondence.

2 According to estimates by the Europol, 10,000 unaccompanied refugee children went missing after arriving to Europe in 2015 (Townsend, 2016).
} 
the intermediate stations for numerous irregular migrants travelling to the desired destinations of Western Europe. Since many of them were intercepted, they reluctantly applied for protection in Croatia, mostly staying shortly and leaving the country within several weeks or months, venturing further West irregularly (Valenta, Zuparic-Iljic and Vidovic, 2015). Due to the closure of the Balkan corridor, the overall number of arrivals in 2016 and 2017 decreased significantly (Bužinkić and Hameršak, 2018). However, from 2001 onwards, the number of unaccompanied children in the total share of irregular migrants intercepted in irregular border crossing in Croatia has increased. This issue is very topical, although less investigated in the Croatian context (cf. Korać Graovac, 2014). An unaccompanied child that enters Croatia as an irregular migrant can become an asylum seeker if s/he seeks protection. In this paper, we focus mainly on the position and status of unaccompanied asylum-seeking and refugee children within the national asylum and integration system in terms of the practices of guardianship and family reunification.

There are many shortcomings related to the procedures and practices of accommodation, guardian appointment, entering the educational process, respecting the special needs and some other aspects of engaging with unaccompanied children. In the previous article (Župarić-Iljić and Mlinarić, 2015), we put a special analytical emphasis on their right to learn the Croatian language and to enter the education system. By providing theoretical remarks and revealing the experiences of practitioners in the field (most notably of special guardians and - to a lesser extent - of other care-providers), in this paper we focussed on the care for unaccompanied children through an analytical examination of the prospects and deficiencies observed in the national systems of children's care and international protection. Thus, the main research questions were to what extent the policies aiming at providing them with care and assistance through the special guardianship model corresponded to the implementation practices in different areas of their status recognition, rights to protection, integration (with)in society and possible family tracing and reunification. Secondly, we were interested in identifying the main structural problems in the organisation of special guardianship care which had already been present in the EU pre-accession period in comparison to the 2015 and 2016 events of "crisis migration" on the Balkan corridor, as well as more recently. 


\section{Children on the move: Basic concepts and theoretical assumptions}

The conceptual definition of "unaccompanied children" leans on the international legal protection mechanisms such as the United Nations' Convention on the Rights of the Child. In this paper, we used the term "unaccompanied child/ren", while also embracing the well-accepted and equally valid phrases included in the Convention - "unaccompanied minors" and "separated children" (UNHCR, 2008). ${ }^{3}$ As opposed to that, the Separated Children in Europe Programme prefers the term "separated" rather than "unaccompanied" because, while some children may be completely alone on their migratory path, others could be with their extended family members who are not their primary or customary caregivers, and are oftentimes are unable to take good care of them. ${ }^{4}$ The Croatian Family Act (2015) uses the term "unaccompanied child", adhering to the concept of the child as defined by the Convention. In this paper, by the term "unaccompanied children" we also understand "separated minors/children"; thus, we may use it interchangeably for those children without parental care or custody.

International research on refugee and unaccompanied children is multidisciplinary and diversified (Anderson, 2001; Bhabha, 2004; Gornik, Sedmak and Sauer, 2018). Those children are often an integral part of "mixed migration" triggered by political instability, economic insecurity and negative consequences of disruptive changes in the human and natural environment (Watters, 2008; Ensor, 2010). Minors may start their journeys with members of their nuclear or extended family, but separation can occur at any stage of the journey. The displacement and separation experience can lead to their physical, psychological and emotional vulnerability as well as to trauma.

\footnotetext{
3 "Unaccompanied children (also called "unaccompanied minors") are children who have been separated from both parents and other relatives and are not being cared for by an adult who, by law or custom, is responsible for doing so. Separated children are those separated from both parents, or from their previous legal or customary primary caregiver, but not necessarily from other relatives. These may, therefore, include children accompanied by other adult family members." (UNHCR, 2008: 7). In the reports related to the "recent refugee situation" the UN agencies also use the term "unaccompanied and separated children" (UNHCR, 2015).

4 "Separated children are under 18 years of age, outside their country of origin and separated from both parents, or their previous legal, or customary primary caregiver. [...] While some separated children are 'accompanied' when they arrive in Europe, the accompanying adult(s) may not necessarily be able, or suitable, to assume responsibility for their care." (Smith, 2009: 3-4).
} 
Children are one of the most vulnerable groups of migrants, often prone to distress, abuse, violence and exploitation. Such trauma can even be prolonged in host countries, influencing their further prospects and attainments within the child welfare and overall integration system, while also having an impact on their chances for effective family tracing and reunification. Disrupted life trajectories and exposure to deprivation and harms very often leads to unfortunate negative psychological, developmental and emotional outcomes (Kohli, 2014; Gornik, Sedmak and Sauer, 2018: 4).

The most common problems faced by unaccompanied and separated children arise from their unresolved legal status, lack of family support and of social networks, their common socio-economic deprivation as well as from institutional and social marginalisation. Researchers warn that there is often a lack of help and support within the educational and social welfare system for refugee and asylum-seeking children, where their victimisation and (re)traumatisation may occur again (Watters, 2008; Pinson, Arnot and Candappa, 2010).

In addition, there are also studies which consider migrant children not only as passive victims, but also as active agents whose migratory experiences may contribute to the growth of their physical and psycho-social resilience to various types of stress, risks and threats (Wernesjö, 2012; Smyth, Shannon and Dolan, 2015). Despite the EU legislative regulations that tend to be homogenous, ${ }^{5}$ in practice, rather diverse and mutually nonaligned policies and practices have oftentimes led to the deprivation of unaccompanied children's rights. These challenges have been thoroughly scrutinised in European national contexts (Gornik, 2009; Barbulescu and Grugel, 2016; Human Rights Watch, 2016).

The institutional efforts of international bodies such as the United Nations' agencies are primarily invested in ensuring that children remain in their respective countries of origin, without being compelled to migrate or forced to flee (Ensor, 2010; Goździak and Ensor, 2016). Secondarily, in the migratory (transiting) phase, focus is placed on the standards and safe-

\footnotetext{
${ }^{5}$ For example, in 2010, the European Commission proposed The Action Plan on Unaccompanied Minors which prescribed the "prevention of unsafe migration and trafficking; reception and procedural guarantees in the EU; identification of durable solutions" including guardian appointment and family tracing (European Commission, 2010: 3). In 2011, the Defence for Children - EPACT published the Core Standards for Guardians of Separated Children in Europe: Goals for Guardians and Authorities, envisaging practical recommendations regarding the role and responsibility of special guardians (Goeman et al., 2011).
} 
guards for protecting the life and integrity of every child. Lastly, during the post-migratory phase, financial and other resources are to be invested in the local integration in the host society, or, if possible, in the means of voluntary return (repatriation) to the areas of origin, as a preferred durable solution. In case of separated children who are being resettled to a third country for the purpose of family reunification, this act could be understood not only as a means of solidarity sharing in-between reception countries, but first and foremost as one of possible durable solutions for those children (cf. UN Committee on the Rights of the Child, 2005: 22-26). However, if local integration in a new community is the most viable option, appointing a special guardian to assist and help a child becomes one of the priority policies and measures, as a prerequisite for the inclusion and overall integration in society, and for further plans for possible reunification with a family. The guardian should take care of the well-being, safety, development and life prospects of a child, always considering their best interests, including family tracing and reunification, and other procedural safeguards (Smith, 2009: 33-43).

The complex issue of the reception and procedure relating to unaccompanied children has recently become a visible topic of research in Croatia. There are studies concerning the legal status and general aspects of the protection and integration of unaccompanied children in Croatia (Kraljević, Marinović and Živković Žigante 2011; Korać Graovac, 2014; Župarić-Iljić and Mlinarić, 2015; Croatian Red Cross, 2016). These studies emphasised and also criticised the fact (oftentimes present in official discourses) that the lack of public clarity regarding the number of unaccompanied children in Croatia and their departure from the country within a few days or weeks impede the implementation of the state programme of care and assistance which is guaranteed by the legal framework. Therefore, effective planning and implementation of further activities concerning their inclusion in the education, social welfare and healthcare system is suspended. By reducing their needs and identities to mere numbers and statistics, the system is stripping itself of the responsibility for durable solutions. In this context, our study seeks to contribute to the discussion on the specific system of guardianship and the role of special guardians in the initial reception, Refugee Status Determination procedure, implementation of further procedural standard actions in regard to the integration of unaccompanied children in Croatia, or their possible reunification with their families in other countries. 


\section{Study aim and methodology}

The overall objective of our initial 2014 research was to describe the legal, institutional and practical aspects of important policy measures concerning unaccompanied children in Croatia in regard to the reception, accommodation, age assessment, guardian appointment, healthcare and social welfare, language learning and education, and the exercise of all other integration rights relating to the specific needs of children as particularly vulnerable categories of migrants and refugees. ${ }^{6}$ The specific objective of this paper is to analyse the policies and measures related to the roles of caregivers, special guardians and primary social welfare workers in regard to the reception, Refugee Status Determination procedure and further social inclusion/integration of unaccompanied children. The results of this study will equally apply to the present situation of unaccompanied and separated children, and contribute to a better understanding and scrutiny of the Croatian asylum and child care systems and of the role of different stakeholders within them.

Firstly, we carried out a desk study of the available documentation and an analysis of the existing research in order to grasp the national legislative and institutional context of care for foreign children with different statuses, most notably those within the Croatian migration and asylum regime. This enabled us to understand the theoretical and methodical standpoints in upto-date research and practice relating to this pertinent issue. Secondly, we carried out a thematic content analysis (cf. Bryman, 2012: 578-581) of the transcripts of 26 expert interviews that were conducted in three cycles, in 2014, 2016, and 2018. Both authors were conducting the interviews and analysing the data. In the first cycle, interviews were conducted by an additional researcher (see footnote 6).

The initial 13 semi-structured expert interviews were conducted from May to July 2014 with representatives of the most relevant national institutions and local parties dealing with the protection of unaccompanied children and assisting asylum seekers and refugees in general. In the case of several interviews, their contents were later amended by additional infor-

\footnotetext{
${ }^{6}$ The Unaccompanied Minors in Croatia - A Comparative Perspective, Analysing the Polices vs. Practices study was conducted in collaboration between the Institute for Migration and Ethnic Studies, Zagreb, Croatia, and the Norwegian University of Stavanger, as part of foreign student Ms Ting Ting's field practice within the European Master in Migration and Intercultural Relations (EMMIR) programme (cf. Župarić-Iljić and Mlinarić, 2015: 336).
} 
mation obtained through follow-up e-mail correspondence. Interviews were conducted with the representatives of the Ministry of the Interior and the Ministry of Social Policy and Youth as the main state parties responsible for dealing with unaccompanied children; Centre for Social Welfare Kutina and Institution for the Education of Children and Juveniles Zagreb, which both arrange accommodation and appoint guardians for unaccompanied children; an elementary school and grammar (engineering) schools in Kutina; as well as of international organisations (UNHCR) and the Croatian Red Cross as leading non-governmental parties in the Croatian asylum system; three NGOs dealing with refugee and children rights (the Croatian Law Centre, Centre for Peace Studies, and Centre for New Initiatives), all of which have dealt with different aspects of unaccompanied children's integration; and of the City Library of Kutina and Evangelic Lutheran Church in Kutina, who were providing integration workshops for asylum seekers.

Four additional interviews with the stakeholders were conducted from February to April 2016; with appointed special guardians (SGs) for unaccompanied children, two of whom were from the Red Cross Zagreb (SG1 and SG2) and two from the Centre for Social Welfare Kutina (SG3 and SG4).

Lastly, from March to May 2018, we interviewed the stakeholders about their reflections on how the 2015 and 2016 Balkan corridor episode had influenced the Croatian system of care for children, on their organisations' roles and responsibilities in regard to the provision of aid and assistance to unaccompanied children, and main challenges they were facing at the moment. Nine more interviews were conducted with: SG1, SG3, an expert from the Croatian Law Centre acting as legal representative of unaccompanied children, two representatives of the Ministry of the Interior working within the Asylum Seekers Reception and Accommodation Centre in Zagreb, a representative of the UNICEF, a representative of the Centre for Missing and Exploited Children, head of the Community Service Centre Zagreb - Dugave (former Institution for the Education of Children and Juveniles Zagreb), an SG from the Centre for Social Welfare Novi Zagreb (SG5), and an SG from the Community Service Centre Zagreb - Dugave (SG6). In sum, we interviewed six persons (two of them twice, in 2016 and in 2018) that were appointed as SGs to unaccompanied children in the period from 2006 to 2018 .

The experts were selected due to their roles, duties, involvement and experiences in dealing with unaccompanied children, providing various 
forms of institutional support and assistance through formal and informal endeavours. Having an insight into the activities of government bodies (including social welfare centres staff appointed as special guardians), international agencies, local civil society organisations, and specific local parties (such as cultural and religious organisations), which all implement specific measures and activities aimed at unaccompanied children and the wider population of people under protection, our approach included diverse and triangular sources of information in a mid-range longitudinal perspective. Because of the ethical implications of the topic, we deliberately decided not to collect voices of unaccompanied and separated children in this study. Instead, we decided to analyse the structural prerequisites for their guardianship care as well as family reunification policies and practices.

\section{Results and discussion}

\subsection{Trends and statistics regarding minor migrants in Croatia}

In Croatia, a significant increase in the numbers of unaccompanied children occurred in 2011 and 2012, and then again in the "post-corridor phase" of 2016 and 2017 (Table 1). According to the Ministry of the Interior, from 2006 to 2018 there was a total number of 4,454 unaccompanied children, of which 883 were asylum seekers, mostly citizens from conflict or war zones: Afghanistan (about 70\%), Syria, Pakistan, Somalia, and Algeria (Zdravković, 2011; Ministry of the Interior, 2018). Almost all of them were males (98\%). ${ }^{7}$ An increase in the number of unaccompanied children in the total share of asylum seekers in Croatia in the 2010s corresponds to trends in the Western EU countries (Menjivar and Perreira, 2017) and in the United States (Linton et al., 2018). In Croatia, for over $75 \%$ of recorded cases, the numbers refer to male population between 16 and 17 years of age, belonging to the category of the so-called adolescents or "older minors". It was impossible to disentangle how many unaccompanied child applicants were granted the status of asylum or subsidiary protection in the period of 2006 to 2018 from the data on status recognition for children in general (those with parents), which counts for 171 asylum and 58 subsidiary protection statuses granted.

\footnotetext{
${ }^{7}$ Considering the problems of data reliability, the UNHCR states that the system of collecting and providing official statistical data on foreign minors in Croatia was uneven back in the 2000s, which contributed to the poor visibility of these children and to misrecognition of their rights and needs (Kraljević, Marinović and Žigante Živković, 2011: 9).
} 
Table 1. Minors with the status of irregular migrants, protection seekers and grantees in Croatia from 2006 to 2018

\begin{tabular}{lcccc}
\hline year & $\begin{array}{c}\text { total number of } \\
\text { foreign minors } \\
\text { with irregular } \\
\text { migrant status }\end{array}$ & $\begin{array}{c}\text { total number of } \\
\text { unaccompanied } \\
\text { children with } \\
\text { irregular migrant } \\
\text { status }\end{array}$ & $\begin{array}{c}\text { total number of } \\
\text { child asylum } \\
\text { seekers }\end{array}$ & $\begin{array}{c}\text { number of } \\
\text { persons aged } \\
\text { 0-17 who were } \\
\text { granted asylum or } \\
\text { subsidiary status }\end{array}$ \\
\hline 2006 & 663 & 562 & - & - \\
\hline 2007 & 612 & 547 & 10 & - \\
\hline 2008 & 173 & 128 & 4 & - \\
\hline 2009 & 166 & 103 & 21 & 7 \\
\hline 2010 & 271 & 172 & 38 & 6 \\
\hline 2011 & 811 & 552 & 197 & 14 \\
\hline 2012 & 1,167 & 726 & 70 & 1 \\
\hline 2013 & 465 & 302 & 55 & $6 *$ \\
\hline 2014 & 362 & 320 & 10 & 34 \\
\hline 2015 & 482 & 149 & $5 *$ & 75 \\
\hline 2016 & 642 & 331 & 164 & 68 \\
\hline 2017 & 891 & 496 & 261 & 229 \\
\hline $2018 * *$ & 189 & 66 & 48 & \\
\hline total & 6,894 & 4,454 & 883 & 5 \\
\hline
\end{tabular}

Source: Ministry of the Interior (2018), authors' adaptation.

* The higher number of minors with obtained protection than of those who applied for it stems from the long recognition procedure. Thus, annual data on application and recognition rates do not necessarily match.

** The data in the first two columns are for the first quarter of 2018 and in the last two columns for the first nine months of 2018.

The fact that unaccompanied children were almost exclusively male minors could be a bit misleading as some of unaccompanied female minors may have remained unrecognised as such, travelling within their groups of extended family members, peers, friends, or compatriots who are not capable of taking good care of them. While not wanting their transient journeys to get interrupted before reaching desired destinations, these underage females might fall victims of trafficking and other forms of exploitation and abuse. As pointed out by Bhabha (2004: 42), professionals and care-providers should be very precautious because "[i]t also appears that traffickers are encouraging abuse of the asylum procedure". This means that those who are in need of protection the most might fail in receiving it by not waiting to obtain it, but rather "buying some time" before continu- 
ing their further transit via dangerous smuggling or trafficking routes. It is indicative that $60 \%$ of unaccompanied children who had been admitted to the Community Service Centre Zagreb - Dugave in the 2011-2017 period left this centre in less than 48 hours, as emphasised by head of the centre.

Before we move on, it is important to briefly outline the reception and accommodation options for unaccompanied children in Croatia. When they apply for protection, these children may be accommodated in three possible ways. If 13 or under, they are accommodated by one of the several child care centres for children without proper parental care (Residential Child Care Institutions) in six cities across the country (Zagreb, Split, Rijeka, Osijek, Karlovac and Ivanec), but mostly in the capital of Zagreb. Minors aged 14 to 16 are usually allocated to centres for the education of children and juveniles with misbehaviour problems, practically serving a role of behaviour-corrective institutions. Finally, those older than 16 might be accommodated in the Reception and Accommodation Centre for Asylum Seekers in Zagreb (opened in 2011, with the capacity of 550 beds). This is mostly the case if they are separated from parents but travelling with other extended family members who are accommodated in the same facility as asylum seekers. Although the Croatian authorities still do not envisage any sensible alternative, unaccompanied children who do not apply for protection are rarely sent to the Aliens Detention Centre in Ježevo. ${ }^{8}$ In case of suspicion and identification of an unaccompanied child as a victim of trafficking, s/he will be accommodated in the national shelter for victims of trafficking or in another alternative accommodation facility.

\subsection{Special guardianship: Building up the system of care}

Leaning on Article 22 of the Convention on the rights of the child, the UN Committee on the Rights of the Child (2005) devised "General comment no. 6 (2005): Treatment of unaccompanied and separated children outside their country of origin", which tackles general and specific protection needs, durable solutions and other important issues at stake, most notably the appointment of a guardian or adviser and legal representative. As an assistant, mediator and care provider who facilitates the practical aspects and procedures for unaccompanied children, appointed special guardians initiate

\footnotetext{
${ }^{8}$ A similar practice of prolonged detainment noted in Slovenia has been criticised by the Slovenian NGOs and the Ombudsman's office, but is ignored and rarely overturned by the authorities who provide no alternative (Žakelj and Lenarčič, 2017: 83).
} 
health examinations for minors, coordinate adequate housing, education and well-being measures, while also enabling the exercise of all children rights in contact and in coordination with other institutions and parties (Goeman et al., 2011; Croatian Red Cross, 2016). In this section, we presented the analyses of some of the most common challenges regarding the appointment of special guardians, their roles in the care system, especially during the Refugee Status Determination procedure, problems of communication, the need for systematic professional trainings, and overall assistance for proper reception and inclusion of unaccompanied children in society.

The main national documents regulating the care for unaccompanied children in Croatia are the Family Act (2015; Article 240), Aliens Act (2018; first adopted in 2003, and amended several times up until 2018) and International and Temporary Protection Act (first adopted in 2003 as Asylum Act, last amended in 2017). The Protocol on the treatment of separated children-foreign nationals (Government of the Republic of Croatia, 2013), which is a successor of the first Protocol on the treatment of unaccompanied children of 2009, devises diverse operational and procedural measures. Current state policies and efforts considering the care for unaccompanied children are based on the new version of the Protocol on the treatment of unaccompanied children dating from August 2018, as the latest amended regulation, featuring many new and more thoroughly devised provisions in comparison to the previous two versions.

The desk-study analysis of the available documents indicated that, according to the legal obligations stemming from the Croatian Family Act (2015; Article 240, paragraph 1, subparagraph 7, and paragraph 5, "[i]n order to protect particular personal and property rights and interests of the child, the social welfare centre or the court will appoint a special guardian to: [...] a foreign national child or a stateless child who is unaccompanied by a legal representative in the territory of the Republic of Croatia". The special guardian should be appointed as soon as possible when a child identified as unaccompanied enters the state territory regardless of his/her possible expression of an intention to seek protection. The guardian stays with the unaccompanied child during the institutionalisation of his/her stay and the entire Refugee Status Determination procedure. Special guardians are appointed by local social welfare centres, mostly among their personnel, but until recently they could also be appointed from the list that was created in 2014 by the former Ministry of Social Policy and Youth, containing 
the names and contacts of educated professionals, i.e. social workers, pedagogues and psychologists who are recognised as care-providing experts. A special guardian could be appointed among the Red Cross personnel, or reception centres for children and juvenile care social workers, operating under some sort of supervision and in communication with local social welfare centres. If an unaccompanied child applies for international protection, he/she will get a legal representative for free legal aid and counselling who will - together with the special guardian - work to inform, prepare and lead the child through the procedure, considering his/her best interest. From then on, the child obtains the rights of an asylum seeker according to the International and Temporary Protection Act. ${ }^{9}$

The role of the special guardian is pivotal during the asylum recognition procedure and the unaccompanied child must be instantly informed about the guardian's appointment. The primary measures concerning the health examination and well-being of unaccompanied children also include formal mechanisms of establishing the identity and age of a minor, the process in which special guardians are included. One respondent (SG6) confirmed that this practice has been rarely utilised, yet he as a guardian always went for the "benefit of the doubt" principle, meaning that he would take seriously the unaccompanied child's alleged statements of his/ her own age.

According to Article 17 of the International and Temporary Protection Act, the application of an unaccompanied child is to be lodged personally, but in the presence of the special guardian, which was also confirmed as a usual practice by our respondents (SG1, SG3). Furthermore, the special guardian has the responsibility to prepare the unaccompanied child for the hearing and provide all the necessary information about the possible procedure outcomes using a language the child can understand and communicate in. Aside from going through the procedural issues re-

\footnotetext{
${ }^{9}$ In this respect, it was stressed by some of our respondents (Red Cross, SG3 and Centre for Peace Studies) that the division of competences and responsibilities with regard to foreign minors between the Ministry of Interior and social welfare centres is somewhat overlapping and often confusing. A lack of inter-agency and intra-agency coordination results in institutional difficulties and inconsistencies in the implementation of existing laws and regulations. This leads to poor coordination and a reduced functionality of the system in the exercise of minors' rights. Nevertheless, the new Protocol envisages the establishing of the Intersectional Committee for the purpose of advancing institutional co-operation between state administration bodies and other stakeholders involved in the protection of unaccompanied children.
} 
lated to the hearing (i.e. interviewing), special guardians also take active role in organising their language learning, school attendance, healthcare and social welfare services. ${ }^{10}$

It seems that all parties working in the system of social welfare of refugees and migrants initially face a great challenge of communication with unaccompanied children (Babić, 2014: 148-149; SG1, SG3). Upon their arrival to Croatia, communication with unaccompanied children is mostly possible in English and sometimes in French. According to the national legislation and the new Protocol, the Ministry of the Interior should provide for translation to a language which the unaccompanied child understands. Communication in other languages is enabled with the help of official translators (most often from Arabic, Farsi, Urdu, and Pashtu) in the phase of initial reception and during the Refugee Status Determination procedure. Unaccompanied children find themselves, overall, in a culturally and linguistically foreign environment. Thus, for children in stressful conditions, the inability to communicate in a familiar language can be particularly frustrating if they cannot express their concerns, needs and problems (Babić, 2014: 149). There is a problem with interpreters and translators who, for the cultural and pedagogical reasons, should be the same gender as the minors (Ministry of the Interior respondent).

The problem of communication in a familiar language is also reflected concerning the appointment of a special guardian. On some occasions, an adult irregular migrant who travelled as a presumed relative in the same group with the minor was appointed guardian just because he could help with the translation. The person might not have had any officially recognised family ties with the child. According to one of our respondents in

$\overline{10}$ As a point of comparison, Slovenia practices three different forms of guardianship. A special guardian is appointed to an unaccompanied child right upon arrival by a regional social welfare centre and according to the Aliens Act, in order to detect the best interests of the child before further procedures for possible status recognition. If a child applies for protection, a legal representative is appointed on the basis of the International Protection Act, with the role of providing support to the child during the Refugee Status Determination procedure. Sedmak and Medarić (2017) stress that the legal representative cares for the best interests of the unaccompanied minor in the recognition procedure, supports him/ her in obtaining the right to healthcare and education, and assists him/her in everyday issues and in contact with institutions. If the unaccompanied child is granted protection status, a guardian is appointed according to the Marriage and Family Relations Act, tasked with the responsibility of enabling foster care and support to the child. However, this is seldom applied because applicants leave Slovenia, which results in the cancellation of procedures (Žakelj and Lenarčič, 2017: 87). 
the 2014 interviewing cycle (Centre for Peace Studies), this was so because the state was looking for "the cheapest way, the cheapest solution. [...] It is a question of money". This practice was abandoned shortly afterwards due to criticism from social workers, negative experiences and trafficking threats (Centre for Social Welfare Kutina, Red Cross, SG3, SG6). Some of the organisations working as refugee-right stakeholders play a supplementary role in helping the state officials with "lending" their translators as an interchangeable human resource they may share. Children are not a homogenous group with the same problems, and even if they are given a chance to be interviewed during the Refugee Status Determination procedure in a language they understand, the problem of their linguistic orientation and adaptation persists. Given the usual shortness of their stay and lack of focussed engagement in learning the Croatian language and remaining in Croatia, their possible acculturation based on language learning remains rather difficult for them.

Furthermore, lack of a proper language orientation practice has led to insufficient and somewhat dysfunctional inclusion of unaccompanied children pupils in educational institutions and in wider society. This could be illustrated by the observation made by one respondent (SG4) that in the period from 2006 to 2013, there were only a dozen of cases in Kutina when unaccompanied children were included in the school system. This was partly a consequence of a previous practice, where some of the unaccompanied children had their special guardians dislocated within the state social institutions. It seems that schools were at disposal as additional supportive institutions for basic socialisation of unaccompanied children, yet were not always utilised for that purpose. ${ }^{11}$

Another particular problem lies in the lack of systematic education and professional training providing specific teaching skills and competencies to caregivers. Special guardians should have the required qualifications and expertise in order to appropriately meet and protect the unaccompanied child's healthcare, social, psychological, educational and any other needs.

\footnotetext{
11 The Red Cross and some NGOs work with unaccompanied children through a nonformal language course as a preparatory phase for formal schooling, but volunteer instructors in this course are not licensed teachers of the Croatian language. Sometimes language courses correspond to their other needs, which concern not only the issues of language acquisition and school curriculum, but more general issues of information about the legal status, integration prospects, family tracing and reunification (Red Cross, SG2, cf. Župarić-Iljić and Mlinarić, 2015).
} 
As emphasised by the report of Herceg Pakšić and Jeđud Borić (2017: 67), the education of social workers, translators and guardians working with unaccompanied children should meet different criteria, including higher education, intercultural competences, previous work experience, cultural sensitivity, inclination to lifelong learning, and teamwork affinity. Even though special guardians should be chosen among well-trained professionals, it seems they are generally in need of more professional trainings, supervisions and support (SG4, SG5, SG6). Education and trainings have been organised by the relevant ministry of social welfare. Specialised workshops were mostly held by social workers having experience with special guardianship, working in the Social Welfare Centre Kutina and Red Cross Zagreb, and by NGOs such as the Centre for Missing and Exploited Children, and other humanitarian parties like the UNHCR (Babić, 2014: 150; SG1, SG3, Institution for the Education of Children and Juveniles Zagreb). The SG1 respondent claims that "[a]side from the education for special guardianship I have taken, which was organised by the UNHCR and the Ministry of Social Policy and Youth, I have experience from exchange programs that included working in an accommodation centre for unaccompanied minors in Denmark", which, in his words, was a valuable transfer of practical knowledge and skills he has cherished from this and similar programs with international colleagues.

The lack of systematic approach to the assistance and care for unaccompanied children in Croatia, common to the period of the 2000s and up to the 2013 EU accession, has lately been tackled by the engagement and proactive role of social workers, individual special guardians and humanitarian organisations specialised in children's rights. Nevertheless, sustainable perspectives of their long-term stay in Croatia still pose a significant task for all stakeholders. From the institutional perspective; by deciding to continue their transit further West in order to reach the desired destinations to join their family, friends or relatives, and/or for any other personal reasons and aspirations, unaccompanied asylum-seeking and refugee children represent a challenge for the state asylum and integration policy, and for the system of care which rather scarcely aims to support their inclusion in the local community where they are accommodated. Furthermore, if they abruptly leave an unfinished Refugee Status Determination procedure, the institutional efforts may be interpreted by some authorities as a waste of human and material resources during the short period 
of the minors' stay. ${ }^{12}$ In this sense, the overlapping competences of the authorities emerge not inasmuch from a genuine willingness to act timely and properly as from a lack of inter-sectoral coordination when it comes to the specific dimensions of reception and further procedures for their stay and integration.

Our respondents have repeatedly noted that the state authorities could benefit from the experience of civil society and other humanitarian parties, because these organisations are internationally networked and willing to share their experience in dealing with foreign minors, mostly children refugees. Some local organisations and international parties are included in the activities of integration of refugee children in society, addressing their specific needs and providing different kinds of assistance, such as translation, legal advising, psychological help, or just socialising with them (the Red Cross, Centre for Peace Studies and Centre for New Initiatives respondents). Through socio-cultural programmes (public events, workshops), they work on the sensibilisation of the local communities concerning the presence of unaccompanied children and other migrants.

Nevertheless, the respondents stressed that the enthusiasm of the NGO sector should not be an excuse for a non-systematic introduction of additional state-funded programmes that could help unaccompanied and separated children to obtain their rights and expectations. Furthermore, some respondents criticised the insufficient (staff and material) capacity and the lack of independent monitoring of the system of guardianship and integration run by the governmental sector (the Croatian Law Centre, Centre for Peace Studies, SG6). On the other hand, the respondents from the state reception and social welfare sector (the Ministry of the Interior, Institution for Education of Children and Juveniles Zagreb, Centre for Social Welfare Kutina) indicated the need for the state to regulate more efficiently the obligation of the unaccompanied children who enter the child-care and asylum system to participate for at least a year in an orientation language learning and educational program, but only if they stay.

\footnotetext{
${ }^{12}$ The research project by the Save the Children and the Centre for Missing and Exploited Children, which included voices of five unaccompanied children, revealed how these boys contemplate leaving Croatia and do not see their future here because Croatia is perceived as not providing enough opportunities: "And this brings us to a vicious cycle: children do not want to stay because there is no built-up care system and plans to integrate them in society, while the system is insufficiently involved in designing activities in that sense because the children will 'leave"' (Herceg Pakšić and Jeđud Borić, 2017: 74).
} 
Finally, since better results of minors' integration were recorded in more multicultural European social environments, there is a recommendation of Croatian centres for social welfare to prepare and allow foster families to accommodate these children (SG5, SG6). This is presumed to be a better socio-psychological path, following the best interests of the child, and a more human, non-institutional accommodation alternative which might ease the eventual integration process during their (presupposed) longer stay in Croatia. Similarly, Herceg Pakšić and Jeđud Borić (2017: 77) report criticism of the current legal settings for special guardianship as improper and advocate for "a new model whereby unaccompanied children would be treated the same as children who are Croatian citizens without adequate parental care".

When asked how the relatively recent structural changes (i.e. joining the EU) and the episode of the Balkan corridor have influenced the reception and integration prospects for unaccompanied children, the respondents (SG1, SG6, Croatian Law Centre, Centre for New Initiatives) agreed that on a legal level, the situation is more "harmonised", however, the institutional practices are lagging behind. A small, but significant improvement in the reception and procedural conditions is noted. It seems that the integration perspectives for unaccompanied children endure hardships and insufficiencies that are somewhat similar to those relating to misimplemented integration measures for adult persons who seek or are under protection (SG3, Centre for Missing and Exploited Children, cf. Valenta, Zuparic-Iljic and Vidovic, 2015).

\subsection{Pertinent role of special guardians in the family reunification process}

Finally, we examined one of the important roles that a special guardian could take on bearing in mind the best interests of the child which is the family reunification process. Many displaced people, including unaccompanied children, are compelled to leave members of their families in the countries of origin or somewhere along the transit path, presumably hoping to be able to accomplish reunification once they are granted protection or some other legal status in a destination/reception country (Goździak and Ensor, 2016). In the context of the host society, an individual assessment of "the best interests of a child" (made mainly by legal representatives and special guardians) is systematically examined in relation to an over- 
all perspective of the refugee-child, the specifics of its cultural heritage, and chances of return, or other durable solutions such as family reunification (Bhabha, 2004). However, this option does not come without legal and practical challenges. Allsopp and Chase (2017) raised the question of whether we could observe family reunification as "the best" durable solution and "the best interest of a child". They doubt the presumption that we should understand it as a uniform and all-fitting model of a child's well-being, especially in cases where children "may be fleeing domestic violence or family-related persecution" (Allsopp and Chase, 2017: 12).

Gornik, Sedmak and Sauer (2018: 13) emphasised that "unaccompanied minors live in a state of chronic uncertainty, without seeing a durable solution", besides having a fear of very probable return (deportation) to their countries of origin once they become of age. Those unaccompanied children who become failed asylum seekers with a status of irregular migrants still may obtain authorised temporary residence on a humanitarian ground, although this is rarely the case both for Slovenia and for Croatia because they usually leave the country. Nonetheless, UN documents and EU treaties, as well as the national legislation mean little if they do not prescribe proper provisions and implementation of national procedures for exercising the best interests of the child, as emphasised by Žakelj and Lenarčič (2017).

On the implementation level, long procedures, lack of documents, procedural costs, and travel expenses are the obstacles noted in the process of family reunification in the EU (European Union Agency for Fundamental Rights, 2016). ${ }^{13}$ The entitlements to family reunification in Croatia have been guaranteed to unaccompanied children asylum claimants who are in the Refugee Status Determination procedure under the provisions of the Dublin Regulation (through the so-called Dublin procedure), or to those granted an asylum or subsidiary protection status according to Article 64(2)

\footnotetext{
${ }^{13}$ Increased arrivals in 2015 and Dublin requests for returns of some migrants (in accordance with the Dublin III Regulation, see: Official Journal of the European Union, 2013) that occurred after the closure of the Balkan corridor have initiated new challenges to family reunification within the EU, which include "[1]ack of counselling and information on Dublin requests for family unity; absence of proof of family relationship, or provision of false information on family members; very lengthy processing of Dublin requests for family reasons [...]; no possibility to appeal negative decisions [...]; burdensome national legislative framework [...]; delays in covering transportation costs in cases of Dublin requests by the competent authorities." (European Union Agency for Fundamental Rights, 2016: 15-16).
} 
of the International and Temporary Protection Act, respecting the best interests of the unaccompanied child. According to the Protocol, if an unaccompanied child does not have family members or relatives in another EU member state or these actually refuse reunification, the regular Refugee Status Determination procedure continues in Croatia (Government of the Republic of Croatia, 2018: 18).

As stated by the Croatian Law Centre respondent, the family reunification procedure triggers the majority of questions unaccompanied children ask their legal representatives in the Refugee Status Determination procedures. According to the International and Temporary Protection Act, family reunification applies only to immediate (nuclear) family members, meaning spouses, parents, and minor children (and siblings). With its last amendments, the definition of family members was extended to include adult, unmarried children and life-long partnership in order to align with the 2003 Council Directive on the Right to Family Reunification (Official Journal of the European Union, 2003). Extended family members (relatives) are also eligible for family reunification but only if they prove they had lived in a country of origin together in the same household and that they had been mutually dependent and had cared for a person (a minor) they want to reunite with.

A request for family reunification can presently be submitted by an unaccompanied minor, with his/her special guardian's consent, but the initiative may come not only from a guardian but also from the institution where the child is accommodated or from the foster family. One of the first steps in the possible reunification with the family is tracing information on their locations, statuses and life trajectories. The International Committee of the Red Cross with its national branches is a leading organisation that deals with family tracing and which, together with the UNICEF, UNHCR and Save the Children, played s crucial role in family tracing and reuniting within the reception and transit centres on the Croatian part of the Balkan corridor. ${ }^{14}$

\footnotetext{
${ }^{14}$ In September 2015, right after the first reception centre in Opatovac (i.e. transit camp) was established, several national parties (the Ministry of the Interior, Ministry of Social Policy and Youth, UNHCR, UNICEF and the Croatian Red Cross) made an agreement (in the form of a temporary Protocol) aimed at providing alternative care for unaccompanied and separated children who were passing through the Opatovac camp. The measures included the usual crisis management activities consisting of immediate medical help, family tracing, and ensuring better reception conditions and proper psychosocial support for children. There were only a few cases in practice where children were not reunited with their families and were moved to children and juvenile centres where they applied for protection.
} 
There is a specific understanding among the stakeholders that this practice of family reunification should be exercised not at all cost and keeping in mind the best interests of all children (SG1, SG6, Centre for Missing and Exploited Children). This topic did not get prominent media and public attention until the Balkan corridor phase, when unaccompanied children were portrayed as one of the most vulnerable groups of forced migrants. Today, there are more organisations and individuals who work as care-providers for minors in Croatia, but only few of special guardians have had experiences of engaging in a family reunification process (most notably from the Red Cross). According to Article 10 of the International and Temporary Protection Act, the special guardian of an unaccompanied child shall undertake all the necessary activities in order to reunite the child with his/her family, if this serves the best interests of the child, including contact and cooperation with the competent ministries (most notably the Ministry of the Interior and Ministry of Social Policy and Youth), other state and foreign bodies, and humanitarian organisations. During the Refugee Status Determination procedure, the special guardian should inform the unaccompanied child applicant of a possibility of reuniting with the family, and this option is usually perceived as the most desired outcome within different national contexts.

In the case of Dublin procedures, a child can be reunited with his/her family members or relatives due to outgoing transfers to another EU country where the rest of the family members obtained or applied for protection. According to the Ministry of the Interior, ${ }^{15}$ since July 2013, the beginning of the implementation of the Dublin procedure, there have been eight successful cases of family reunification in Croatia where an unaccompanied asylum-seeking child was transferred to another EU member state to join his/her family members. Out of all the unaccompanied children who have been granted some sort of protection status in Croatia, none have been transferred to any other state for the reason of family reunification so far. Only one case of reunification has been realised in Croatia for two minor refugee children (who came with their adult sibling) via the incoming transfer of their parents as part of the resettlement quota scheme. We are not aware of any voluntary returns of unaccompanied minors to their countries

\footnotetext{
15 The Ministry of the Interior's official reply to "Molba za dostavom podataka oko maloljetnika bez pratnje [A Request for Information about Unaccompanied Minors]" (private e-mail correspondence).
} 
of origin, nor do we know of cases of forced deportations of this population on an individual basis. Nevertheless, what has attracted prominent media and public attention lately are the disturbing news on the practices of deterrence and presumably violent push-back of irregular migrants on the Bosnian and Herzegovinian and Croatian borders, as indicated by humanitarian parties (Human Rights Watch, 2018). One could assume there might be some accompanied or separated minors among those stranded on the borders without prospects of further movement in harsh winter conditions.

According to our respondents, a myriad of potential obstacles arise when it comes to planning and implementing family reunification. In general, it is very difficult to collect and provide all the documentation necessary as proof of kinship, such as birth or wedding certificates. Obtaining these documents through the Croatian embassies in Turkey or Egypt for people from war-torn areas has been almost impossible, along with administrative conundrums while obtaining official translations of these documents into Croatian in these countries, and paying consular fees. If approved for reunification, travel expenses and costs have to be paid by the applicants, and only the reunifications carried out under the Dublin III Regulation are exempted from this rule. The Croatian Law Centre respondent stresses that the most difficult cases she has encountered as a legal representative of unaccompanied children are those "[...] of tracing and reunifying children with children. So, an unaccompanied child is here [in Croatia], and other unaccompanied children who are his underage brothers or sisters are in another country. These are terribly vulnerable groups". This example shows that the contacts and cooperation of special guardians and legal representatives and other care-providers in Croatia and in a country where they will come from, or will be reunited to, are crucial.

The Kutina Social Welfare Centre respondent emphasised that, when it comes to family reunification, instead of making decisions for him/her, a special guardian should always act responsible and take into account the child's "opinions, thoughts and wishes", and try to connect those with real options and the child's best interests of. SG1 finds gaining the trust of unaccompanied children by maintaining a close professional and friendly relationship with them to be the most important task in his work with minors, especially considering the fact that many unaccompanied children might be unaware of their rights and of the special guardian's role and responsibilities. A special guardian from the Red Cross may rely on the family tracing 
service of the International Committee of Red Cross called the Restoring Family Links programme. This service is not at direct disposal to other special guardians, and SG1 claimed this has made his job on family reunification easier. By examining the facts about the child's trajectories, SG1, with the help of translators, asks an unaccompanied child to draw a family tree and to talk openly about his/her family life. Occasionally, special guardians use help and ask for the assistance of other social welfare workers and professionals (pedagogues, psychologists, and educators), or humanitarian organisations present in the field, such as the UNICEF, UNHCR or Save the Children, and others (SG4, SG6).

Lastly, it seems that the Balkan corridor episode has influenced the role of special guardians in a family reunification process first and foremost in a sense that much more of family tracing services were used during the massive arrival and transit of refugees and migrants, and in its aftermath. After the Corridor ceased to exist, more of family tracing and reunification cases were handled by the Red Cross service in regular procedures or as part of the Dublin III return cases. The focus of the authorities, levels of education and trainings provided as well as the overall engagement towards unaccompanied children have risen, together with the involvement of new humanitarian parties in this respect. Nonetheless, it is still an ongoing challenge for special guardians to manage the life trajectories of unaccompanied and separated children and to reunite them with their family members, if this is a convenient and viable option, without hurting the child's rights, freedoms or integrity.

\section{Concluding remarks: Overcoming institutional challenges for longer-term solutions?}

The limitations of this research relate first and foremost to the decision not to include unaccompanied children as possible respondents. This approach lacks in personal stories and testimonies from the very subjects of our research, but was chosen due to the sensitivity of the topic, ethical concerns relating to gaining the trust of (foreign) children and interviewing them, and practical considerations in regard to the organisation of translation and other assistance in the interviewing process. Nevertheless, the multifaceted perspectives of different parties (policy makers and practitioners) included in our research emphasised the stakeholders' standings on the issue. Hopefully, this institutional perspective will be expanded in future research 
through children's voices in order to critically re-examine our findings and gain more salient features of their status, prospects and overall reflections on the system of care. The results of such research would provide more specific, evidence-based policy recommendations for the improvement of longer-term perspectives of unaccompanied children in Croatia.

We found that the Croatian legal framework is fairly harmonised with the EU standards, and our results show that the practices of appointing a special guardian for unaccompanied child are among the priority activities of the official bodies. Regulating their status through a special type of institutional accommodation, assisting them in communication with the administration and fostering their best interests has been a prominent task for any special guardian. In their work with unaccompanied children, careproviders encounter very challenging tasks, yet, their role is indispensable for the further prospects and interests of a child. A significant problem still remains that special guardians appointed among social welfare centres staff are lacking the capacity and time to focus only on providing assistance to unaccompanied children because of their regular job obligations, which sometimes result in their inability to respond to the specific needs of a child. Minors are provided with accommodation, healthcare and social welfare, including legal and financial support. At a later stage, upon status recognition, it is possible to start the family reunification process, adhering to the principle of "the best interests of a child", where special guardians should have a prominent role. In this respect, special guardians and other care-providers need more education and training in recognising whether this solution is durable and serves the best interests of the child, or there are better alternatives.

Due to the transit character and further irregular movement of the majority of unaccompanied children, their exercise of legal rights and inclusion in Croatian society is given only secondary importance. According to some state parties (the Ministry of the Interior, Ministry of Social Policy and Youth, Institution for the Education of Children and Juveniles Zagreb), the main reason for insufficient access to many of the guaranteed rights of unaccompanied children is their short stay and arbitrary withdrawal from the care system and the Refugee Status Determination procedure within just a few days and weeks following their arrival. This results in "wasting" state and non-state resources without any real benefits for the children. Even though the state, as the signatory party of the Convention on the Rights 
of the Child, recognises all the rights that the convention guarantees, very often it is hard to utilise and implement these rights in practice. For example, the official attitude of the authorities is that unaccompanied children are generally reluctant to stay and attend school or engage in other forms of integration activities, which seems as a strategy of "shaming and blaming" the disadvantaged, as a sort of a (non)policy that is difficult to legitimise. Instead, an alternative approach could question the inherent inconsistencies of the Croatian reception and integration system for the unaccompanied children's care and bring in the assessment of their needs based on swift and adequate systematic responses, as indicated by Herceg Pakšić and Jeđud Borić (2017: 74-80).

However, even for those unaccompanied children who remain longer, their guaranteed rights are unlikely to be fully exercised in practice for the reason of the institutions' disbelief in their genuine intention to stay. This is a noteworthy phenomenon stressed in 2014 as well as in 2018 by international parties (the UNHCR and UNICEF respondents). The problem of a significant discrepancy between the prescribed legal regulations and recommended good models and daily practices of integration has also been noticed in some neighbouring countries such as Slovenia (Sedmak and Medarić, 2017). In Croatia, the activities of humanitarian parties in the period from 2008 to 2018 have shown improvements in the system of care for unaccompanied children, although our analysis showed that there are still some challenges to tackle and institutional obstacles to resolve. Therefore, we conclude that in Croatia, unaccompanied children have insecure, yet somewhat elementary prospects for the future. If they decide to continue their irregular journeys, they may fall into the traps of being deceived by smugglers or become victims of trafficking, violence and exploitation. Therefore, an alternative humanitarian status and complementary forms of protection should always be considered as other probable options (UN Committee on the Rights of the Child, 2005: 21). This is envisaged in the new Croatian Protocol, however, since this is a very recent document, its results still remain to be proven. The new Protocol has been updated and devised partly as an answer to increased numbers of unaccompanied children at the Croatian borders following the closure of the Balkan corridor, and as a remedy for the observed fallacies of the system. Therefore, high hopes are put into its implementation in order to fill the child care and protection gaps by more precise defini- 
tions of roles, rights, obligations and responsibilities, while also including children's agency in the process.

Finally, the support of professional interpreters and intercultural mediators is required by legal representatives and other care-providers (professional staff) working with and for foreign (refugee and migrant) children in order to overcome linguistic and intercultural barriers. Therefore, more efficient coordination of activities and inter-sectoral cooperation for mutual learning has been recognised as important in fulfilling the special guardians' demanding obligations towards unaccompanied children. Providing assistance and counselling are the main role of special guardians aimed at ensuring comprehensive protection of unaccompanied children's rights, meaning adequate reception, fair procedure, effective integration and possible family reunification. Acknowledging the specificities of working with vulnerable groups of foreign children, our respondents opted for more learning programmes in the forms of focussed professional trainings and a system of support network, mentoring and supervision for special guardians.

Lastly, what is definitely lacking in the Croatian context, and what our analysis addressed only partly, is a more coherent and more engaged effort towards durable solutions for any migrant or refugee child, even when they reach maturity. There is no doubt that more precise data on unaccompanied children and more sensitive national practices of children care are needed in order to implement effective solutions on family tracing and reunification. Such solutions would critically examine and implement the best interests of the child principle on a case-to-case basis. Future research should include a more extensive analysis of the consequences of the Balkan corridor's closure and further derogation of refugee rights in Europe on the life prospects and statuses of unaccompanied children, and of the ways in which this situation might diverge from the proclaimed international standards of human rights and children care, which all European countries are obliged to follow. Reduced chances of getting to a territory and applying for protection unveil as a result of the tightening of border regimes in (the) EU(rope) and the overall securitisation of asylum and migration policies, which have direct consequences on the life prospects of unaccompanied children, those who are stranded in poor conditions at sealed borders or within unfamiliar reception facilities of inefficient humanitarian regimes they opt to leave. Therefore, this 
analysis pointed to current challenges and pitfalls of the protection of unaccompanied and separated children in Croatia that future analyses can build on.

\section{REFERENCES}

Allsopp, Jennifer and Chase, Elaine (2017). "Best interests, durable solutions and belonging: Policy discourses shaping the futures of unaccompanied migrant and refugee minors coming of age in Europe", Journal of Ethnic and Migration Studies, 45 (2): 293-311. doi: 10.1080/1369183X.2017.1404265

Anderson, Philip (2001). “'You Don't Belong Here in Germany...': On the Social Situation of Refugee Children in Germany", Journal of Refugee Studies, 14 (2): 187-199. doi: 10.1093/jrs/14.2.187

Babić, Gordana (2014). "Privremena skrb za djecu bez pratnje strane državljane u Prihvatnoj stanici Doma za odgoj djece i mladeži Zagreb [Temporary Care for Unaccompanied Foreign National Children at the Recpetion facility of the Institution for Education of Children and Juveniles Zagreb]", in: Aleksandra Korać Graovac (ed). Pravna zaštita djece bez pratnje. Zagreb: Pravni fakultet, pp. 145-153.

Barbulescu, Roxana and Grugel, Jean (2016). "Unaccompanied minors, migration control and human rights at the EU's southern border: The role and limits of civil society activism", Migration Studies, 4 (2): 253-272. doi: 10.1093/migration/mnw001

Bhabha, Jacqueline (2004). "Seeking Asylum Alone: Treatment of Separated and Trafficked Children in Need of Refugee Protection", International Migration, 42 (1): 141-148. doi: 10.1111/j.0020-7985.2004.00277.x

Bryman, Alan (2012). Social Research Methods. New York: Oxford University Press.

Bužinkić, Emina and Hameršak, Marijana (eds.) (2018). Formation and Disintegration of the Balkan Refugee Corridor: Camps, Routes and Borders in Croatian Context. Zagreb: Institute of Ethnology and Folklore Research, Centre for Peace Studies, and Faculty of Political Science. München: bordermonitoring. eu.

Croatian Red Cross (2016). Vodič za skrbnike djece bez pratnje, stranih državljana $u$ Republici Hrvatskoj [Guidebook for guardians of unaccompanied foreign national children in the Republic of Croatia]. Zagreb: Croatian Red Cross.

Ensor, Marisa (2010). "Understanding Migrant Children: Conceptualizations, Approaches, and Issues", in: Marisa Ensor and Elzbieta Gozdźiak (eds). Children and Migration: At the Crossroads of Resiliency and Vulnerability. New York: Palgrave Macmillan, pp. 15-35.

European Commission (2010). The Action Plan on Unaccompanied Minors. Brussels: European Commission.

European Union Agency for Fundamental Rights (2016). FRA Monthly data collection on the current migration situation in the EU. Thematic focus: Fa- 
mily tracing and family reunification. Vienna: European Union Agency for Fundamental Rights.

Goeman, Marine, van Os, Carla, Bellander, Eva et al. (2011). Core Standards for Guardians of Separated Children in Europe: Goals for Guardians and Authorities. Leiden: Defence for Children - ECPAT The Netherlands.

Gornik, Barbara (2009). "Mladoletni migranti brez spremstva in njihove pravice v slovenskem azilnem in migracijskem sistemu [Unaccompanied minor migrants and their rights in Slovenian asylum and migration system]", Razprave in gradivo, 60: 118-141.

Gornik, Barbara, Sedmak, Mateja and Sauer, Brigit (2018). "Introduction - Unaccompanied minor migrants in Europe: Between compassion and repression", in: Mateja Sedmak, Birgit Sauer and Barbara Gornik (eds). Unaccompanied Children in European Migration and Asylum Practices: In Whose Best Interest? Oxon: Routledge, pp. 1-15.

Government of the Republic of Croatia (2013). Protokol o postupanju prema djeci odvojenoj od roditelja - stranim državljanima [Protocol on the treatment of unaccompanied children - Foreign nationals]. Zagreb: Government of the Republic of Croatia.

Government of the Republic of Croatia (2018). Protokol o postupanju prema djeci bez pratnje [Protocol on the treatment of unaccompanied children]. Zagreb: Government of the Republic of Croatia.

Goździak, Elżbieta and Ensor, Marisa (2016). "Conclusion: Durable Solutions During Transient Years - Lessons Learned", in: Marisa Ensor and Elżbieta Goździak (eds.) Children and Forced Migration: Durable Solutions During Transient Years. Cham: Palgrave Macmillan, pp. 355-371.

Herceg Pakšić, Barbara and Jeđud Borić, Ivana (2017.) Final report: Needs assessment for capacity building in the protection system of unaccompanied children. Zagreb: Save the Children, Center for Missing and Exploited Children in Osijek.

Human Rights Watch (2016). “'Why Are You Keeping Me Here?' Unaccompanied Children Detained in Greece". https://www.hrw.org/report/2016/09/08/why-areyou-keeping-me-here/unaccompanied-children-detained-greece.

Human Rights Watch (2018). "Croatia: Migrants Pushed Back to Bosnia and Herzegovina. Violence, Abuse, Denied Opportunity to Apply for Asylum”. https:// www.hrw.org/news/2018/12/11/croatia-migrants-pushed-back-bosnia-and-herzegovina.

Kohli, Ravi K. S. (2014). "Protecting asylum seeking children on the move", Revue Européenne des Migrations Internationales, 30 (1): 83-104. doi: 10.4000/ remi.6768

Korać Graovac, Aleksandra (ed.) (2014). Pravna zaštita djece bez pratnje [Legal protection of unaccompanied children]. Zagreb: Pravni fakultet.

Kraljević, Radojka, Marinović, Lovorka and Žigante Živković, Branka (2011). Djeca bez pratnje strani državljani u Republici Hrvatskoj [Unaccompanied Migrant Children in the Republic of Croatia]. Zagreb: UNHCR.

Linton, Julie, Kennedy, Elizabeth, Shapiro, Alan and Griffin, Marsha (2018). "Unaccompanied children seeking safe haven: Providing care and supporting well- 
being of a vulnerable population", Children and Youth Services Review, 92: 122-132. doi: 10.1016/j.childyouth.2018.03.043

Menjívar, Cecilia and Perreira, Krista (2017). "Undocumented and unaccompanied: Children of migration in the European Union and the United States", Journal of Ethnic and Migration Studies, 45 (2): 197-217. doi: 10.1080/1369183X.2017.1404255

Ministry of the Interior (2018). Statistički pokazatelji osoba kojima je odobrena međunarodna zaštita u Republici Hrvatskoj zaključno do 30.09.2018. [Statistical indicators of persons granted with international protection in the Republic of Croatia until 30 September 2018]. Zagreb: Ministry of the Interior.

Official Journal of the European Union (2003). Council Directive 2003/86/EC of 22 September 2003 on the right to family reunification. https://www.easo.europa.eu/sites/default/files/public/Family-Reunification-EN.pdf.

Official Journal of the European Union (2013). REGULATION (EU) No 604/2013 OF THE EUROPEAN PARLIAMENT AND OF THE COUNCIL of 26 June 2013 establishing the criteria and mechanisms for determining the Member State responsible for examining an application for international protection lodged in one of the Member States by a third-country national or a stateless person (recast). https://eur-lex.europa.eu/eli/reg/2013/604/oj.

Pinson, Halleli, Arnot, Madeleine and Candappa, Mano (2010). Education, Asylum and the 'Non-Citizen' Child: The Politics of Compassion and Belonging. New York: Palgrave Macmillan.

Sedmak, Mateja and Medarić, Zorana (2017). "Life transitions of the unaccompanied migrant children in Slovenia: Subjective views", Dve domovini, 45: 61-77.

Smith, Terry (ed.) (2009). Separated Children in Europe Programme: Statement of Good Practice (4th Revised Edition). Copenhagen: Save the Children.

Smyth, Berni, Shannon, Marry and Dolan, Pat (2015). "Transcending borders: Social support and resilience, the case of separated children", Transnational Social Review, 5 (3): 274-295. doi: 10.1080/21931674.2015.1074430

The Aliens Act (2018). Official Gazette of the Republic of Croatia, 46. http:// www.tranexp.hr/PDF/The_Aliens_Act_2013.pdf.

The Family Act (2015). Official Gazette of the Republic of Croatia, 103. https:// www.pravo.unizg.hr/_download/repository/Croatian_family_act_-_unofficial_ translation $\% 5 \mathrm{~B} 1 \% 5 \mathrm{D} . \mathrm{doc}$.

Townsend, Mark (2016). "10,000 refugee children are missing, says Europol”, The Guardian, January 30. https://www.theguardian.com/world/2016/jan/30/fearsfor-missing-child-refugees.

UN Committee on the Rights of the Child (2005). General comment No. 6 (2005): Treatment of Unaccompanied and Separated Children Outside their Country of Origin. https://www.refworld.org/docid/42dd174b4.html.

UNHCR (2008). UNHCR Guidelines on Determining the Best Interests of the Child. https://www.unhcr.org/4566b16b2.pdf.

UNHCR (2015). Europe Refugee Emergency - Briefing Note: Unaccompanied and separated children. http://data.unhcr.org/mediterranean/download.php?id=85.

UNICEF (2016). Uprooted: The growing crisis for refugee and migrant children. https://www.unicef.org/videoaudio/PDFs/Uprooted.pdf. 
UNICEF (2017). A child is a child: Protecting children on the move from violence, abuse and exploitation. https://www.unicef.org/publications/files/UNICEF_A child_is_a_child_May_2017_EN.pdf.

Valenta, Marko; Zuparic-Iljic, Drago and Vidovic, Tea (2015). "The Reluctant Asylum-Seekers: Migrants at the Southeastern Frontiers of the European Migration System”, Refugee Survey Quarterly, 34 (3): 95-113. doi: 10.1093/rsq/ hdv009

Watters, Charles (2008). Refugee Children: Towards the Next Horizon. Oxon: Routledge.

Wernesjö, Ulrika (2012). "Unaccompanied asylum-seeking children: Whose perspective?", Childhood, 19 (4): 495-507. doi: 10.1177/0907568211429625

Zdravković, Lana (2011). Country report: Integrating Asylum Minors in Croatia. Sofia: Center for the study of the Democracy.

Žakelj, Tjaša and Lenarčič, Blaž (2017). "Determination of the best interest of unaccompanied minors in Slovenia", Dve domovini, 45: 79-95.

Župarić-Iljić, Drago and Mlinarić, Dubravka (2015). "Strani maloljetnici bez pratnje u Republici Hrvatskoj: Problematika učenja jezika i obrazovanja [Foreign Unaccompanied Minors in the Republic of Croatia: the Issue of Language Learning and Education]", Migracijske i etničke teme, 31 (3): 333-363. doi: 10.11567/met.31.3.1

\title{
Skrb za djecu bez pratnje u Hrvatskoj: uloge i iskustva posebnih skrbnika
}

\author{
Drago ŽUPARIĆ-ILJIĆ \\ Odsjek za sociologiju, Filozofski fakultet Sveučilišta u Zagrebu, Hrvatska \\ dzuparic@ffzg.hr
}

Dubravka MLINARIĆ

Institut za migracije i narodnosti, Zagreb, Hrvatska

dubravka.mlinaric@imin.hr

U razdoblju između 2011. i 2017. došlo je do oscilirajućeg, ali vidljivog, porasta broja maloljetnika bez pratnje u tranzitu kroz Hrvatsku. Događaji na balkanskom koridoru tijekom 2015. i 2016. uključivali su i značajan broj djece bez pratnje i djece odvojene od roditelja, koji se smatraju ranjivim skupinama izbjeglica i migranata. Državne politike i mjere usmjerene na skrb za te skupine, odnosno na njihovu zaštitu, uključuju i mehanizme imenovanja posebnih skrbnika koji se bave zaštitom njihovih prava i pružanjem opće potpore u sustavu skrbi tijekom njihova boravka i/ili tijekom postupka priznavanja statusa. Provedenom analizom dostupnih dokumenata nadopunjenom tematskom analizom sadržaja 26 ekspertnih intervjua koji su bili provedeni u tri ciklusa, 2014., 2016. i 2018., među relevantnim dionicima i pružateljima skrbi, u radu se razmatraju neki od najvažnijih 
izazova u sustavu posebnog skrbništva, ispitujući opću ulogu skrbnika za prihvat, integraciju i moguće spajanje obitelji za djecu bez pratnje. Rezultati upućuju na to da se zbog kratkog razdoblja boravka djece bez pratnje u Hrvatskoj, ali i zbog sustavnih nedostataka u sustavu skrbi, država suočava s nedosljednostima u provedbi postojećih standarda Europske unije kao i nacionalnih mjera. Stoga je sustav posebnog skrbništva za maloljetnike bez pratnje i djecu odvojenu od roditelja, na koji je samo dijelom utjecalo iskustvo $\mathrm{s}$ balkanskim koridorom iz 2015. i 2016., ograničen nedostatkom stručnih i financijskih sredstava, izostankom snažnije institucionalne podrške angažmanu posebnih skrbnika te donekle preklapanjem nadležnosti različitih aktera u sustavu skrbi.

Ključne riječi: djeca bez pratnje, posebno skrbništvo, spajanje obitelji, azil u Hrvatskoj, Balkanski koridor 